\title{
LIQUIDITY RISK MANAGEMENT OF BANKS BELONGING TO ERSTE GROUP AND SOCIETE GENERALE GROUP
}

\author{
[Management rizika likvidity bank patř́cích do skupiny Erste Group a Societe \\ Generale Group]
}

\author{
Tomáš Gongol ${ }^{1}$, Pavla Klepková Vodová ${ }^{2}$ \\ ${ }^{1}$ Slezská univerzita, Obchodně podnikatelská fakulta, Univerzitní nám. 1934/3,733 40 Karviná \\ Email:gongol@opf.slu.cz \\ ${ }^{2}$ Slezská univerzita, Obchodně podnikatelská fakulta, Univerzitní nám. 1934/3,733 40 Karviná \\ Email:klepkova@opf.slu.cz.
}

\begin{abstract}
The aim of this paper was to compare the strategy of liquidity risk management of banks belonging to Erste Group and Societe Generale Group in the region of Central and Eastern Europe. We have used three liquidity ratios and compared values of these ratios of subsidiary banks, parent banks and corresponding banking sectors. The results confirmed that each bank has own strategy which combines defensive and offensive approaches to liquidity. In terms of sources of funding, subsidiaries are much safer than both parents bank. Concerning the buffer of liquid assets, Societe Generale as a parent bank is much more liquid than its subsidiaries and also than Erste Group Bank and its subsidiaries. Differences between values of all ratios for parent banks, subsidiaries and corresponding banking sectors are statistically significant which is proved by the analysis of variance for a single factor.
\end{abstract}

Keywords: financial group, liquid assets, liquidity, net interbank position, strategy of liquidity risk management.

JEL classification: G21, G01, G32

Doručeno redakci: 2.3.2015; Recenzováno: 13.3.2015; 15.3.2015; Schváleno k publikování: 27.5.2015

\section{Introduction}

The emergence of financial conglomerates is one of the major trends in the financial sector in recent years. In the most general sense, a financial conglomerate is a group of entities whose primary business is financial and whose regulated entities engage to a significant extent in at least two of the activities of banking, insurance and securities (Joint Forum, 1999). There are many motives for conglomeration; however, it should not be omitted that financial conglomerates are very often linked also with higher risks. Looking at the variety of banking business risks, we will focus on liquidity risk. The insufficient liquidity of a bank may lead to a situation when the majority of depositors intend to withdraw their funds which will cause a bank run. This situation is very dangerous even for healthy banks. In fact, no bank is able to repay all its depositors their funds if there is a run on the bank. Banks also provide medium and long term loans; therefore they maintain the level of cash and other liquid assets only at the necessary level. Additionally, the problem of one bank may quickly spread to the whole banking sector and result in a bank panic. Especially during the global financial crisis, the importance of liquidity risk has been revised significantly.

It is evident that when it comes to managing the liquidity and liquidity risk properly, each bank has to have an adequate strategy of liquidity risk management. Such a strategy can be assessed also with the use of liquidity ratios. Erste Group and Societe Generale Group belong to the largest financial conglomerates in the Central and Eastern Europe (CEE countries). The aim of this paper is therefore to compare the strategy of liquidity risk management of banks 
belonging to these two financial groups. The paper is structured as follows. The next section gives the theoretical background of liquidity risk and its management. Then we focus on the methodology, data and results of liquidity ratios. The last section captures concluding remarks.

\section{Liquidity risk management}

Liquidity risk can be defined as the risk that a bank, though solvent, either does not have enough financial resources to allow it to meet its obligation as they fall due, or can obtain such funds only at excessive costs (Vento and La Ganga, 2009). The bank is able to satisfy the demand for money, and hence is liquid, as long as at each point in time outflows of money are smaller or equal to inflows plus the stock of money held by a bank. If outflows are larger than inflows and the stock of money, there is a deficit which has to be financed. To ensure that the bank will be liquid at any time, adequate liquidity risk management is essential. The aims of liquidity risk management are: (i) to ensure that all times an adequate corresponding balance between cash inflows and cash outflows, thus guaranteeing the solvency of the bank; (ii) to coordinate the issuing by the bank of short, medium and long term financing instruments; (iii) to optimize the costs of refinancing, striking a trade-off balance between liquidity and profitability; and (iv) to optimize, for banks structured as banking groups, the intra-group management of cash flows, with the aim of reducing dependence on external financial requirements, by means of cash pooling techniques or other optimization instruments (Ruozi and Ferrari, 2013).

Figure 1: Process of liquidity risk management

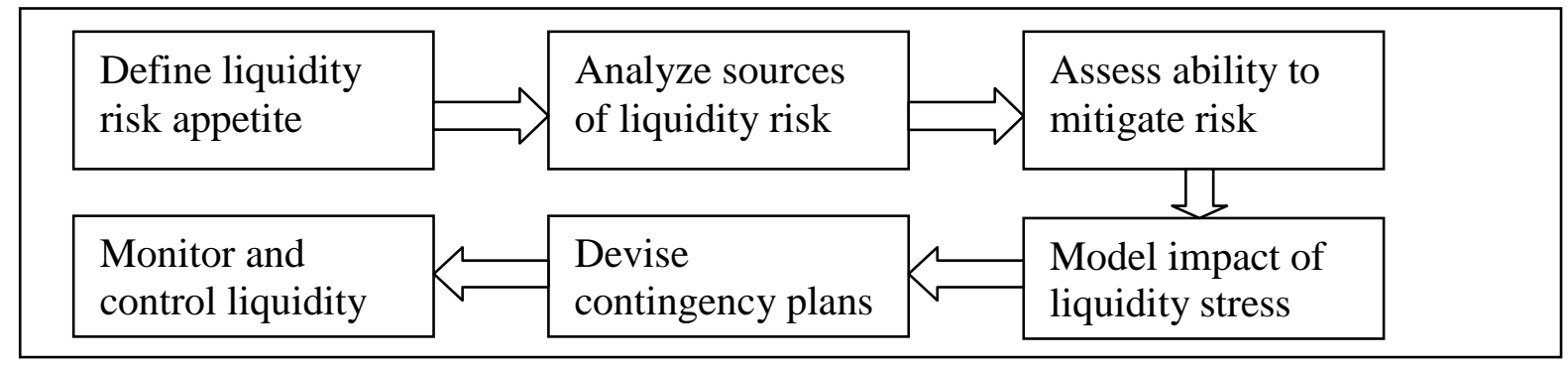

Source: Vodová (2013b, p. 24).

The process of liquidity risk management varies according to the size of the bank, its prevalent activities, its level of internationalization, and its relative organizational complexity. Figure 1 describes the process of liquidity risk management. First we need to define risk appetite (the acceptable level of risk). The bank has to take into account the regulatory requirements, internal constraints, key shareholders' objectives and other external factors. The value of an acceptable level of risk may be in the following forms: an acceptable percentage of the maturity mismatch of assets and liabilities within the specified time horizon, limits of concentration of funding sources, limits of funding with foreign currency sources or minimum required values of selected liquidity ratios. Methods of liquidity risk measurement and management are described and applied e.g. by Angermüller and Zeranski (2008). After that, it is necessary to analyze all banking business in order to determine all sources of liquidity risk. Liquidity risk consists of central bank liquidity risk, funding liquidity risk, and market liquidity risk (Nikolau, 2009). Central bank liquidity risk is a risk that a central bank would not be able to supply in terms of the liquidity needed to the financial system. Funding liquidity risk is the risk that the bank would not be able to efficiently meet both expected and unexpected current and future cash flow and collateral needs without affecting either daily operation or the financial condition of the bank. Market liquidity risk is the risk that a bank 
cannot easily offset or eliminate a position at the market price because of an inadequate market depth or market disruption (BIS, 2006).

The bank will then assess the possibilities of liquidity risk mitigation. The bank has to check access to funding lines and repo agreements, to assess the volume and quality of the liquid assets. The sufficient diversification of funding sources and sufficient amount of deposits, particularly retail deposits, is preferred. It is also needed to model the impact of liquidity shocks by using scenario analysis or stress testing. Knowledge of the impact of the liquidity shock can be used for devising an effective contingency plan which will enable the bank to survive the crisis period. The bank also must continuously monitor and control liquidity (Choudhry, 2012). The whole process must be in compliance with current legislative rules which are described e.g. in Gongol and Vodová (2014) who focused also on the new legislation based on Basel III rules and minimum standards of liquidity: Liquidity Coverage Ratio and Net Stable Funding Ratio.

While managing liquidity risk, we can distinguish two approaches: defensive and offensive strategies. Typically, any bank has an own strategy which is somewhere between these two extremes, as it is necessary to balance between two important banking business aspects: liquidity and profitability. The defensive strategy is associated with the holding of liquid assets; this means a lower liquidity risk but at the same time low profits (cash bears no yields at all, yields of other categories of liquid assets are very limited). A pure defensive strategy thus has a negative impact on the bank profitability. On the contrary, the aim of the offensive strategy is to reach such liquidity positions so that the bank would be able to invest and to provide loans whenever it is profitable. Table 1 shows also other differences between these two approaches.

Table 1: Defensive and offensive approach to liquidity risk management

\begin{tabular}{|l|l|l|}
\hline Definition & Defensive strategy & Offensive strategy \\
\hline Focus & ability to fund all cash outflows & $\begin{array}{l}\text { ability to obtain funds at a price } \\
\text { lower than the expected yield on } \\
\text { loans/investments }\end{array}$ \\
\hline Main source of liquidity & contractual maturities & reinvestment performance \\
\hline Typical institutions & assets & liabilities \\
\hline How often to monitor the liq. position & small banks & $\begin{array}{l}\text { large banks, branches of foreign } \\
\text { banks }\end{array}$ \\
\hline $\begin{array}{l}\text { Commonly used liquid. indicators: } \\
\text { loan to deposit ratio } \\
\text { liquid assets to volatile liabilities }\end{array}$ & $\begin{array}{l}\text { low } \\
\text { high }\end{array}$ & very often \\
\hline
\end{tabular}

Source: Vodová (2013b, p. 26).

Focusing on the costs of liquidity, we have to distinguish both type of the liquidity risk and the strategy of its management. Funding liquidity risk is more connected with opportunity costs of holding cash and other liquid assets than market liquidity risk which is more linked to the development of asset prices which reflect liquidity costs (Nikolau, 2009). At the same time, almost the same is true for defensive and offensive strategy, where the first of them generates costs of holding liquidity.

In case of a financial conglomerate, we should take into consideration also the possibility of intra-group support. The probability that intra-group supports occurs is confirmed by the survey of Bank for International Settlements. According to the findings of this survey (BIS, 2012), financial groups which encountered problems between 2007 and 2009 during the financial crisis typically had to consider the question of intra-group support. Intra-group liquidity support consists of various types of support measures, such as (a) a credit or a credit 
line provided by one entity to another entity within the group; (b) intra-group cross shareholdings; (c) trading operations whereby one group entity deals with or on behalf of another group entity; (d) central management of short-term liquidity within the group and $(\mathrm{g})$ guarantees and commitments provided to or received from other companies in the group. Support measures may exist in the form of upstream support (support provided by a subsidiary to its parent) or downstream support (support provided by a parent to its subsidiary). Both types of support typically increase the risk of loss to the provider and adversely affect its solvency, liquidity and profitability.

A large number of studies focus on bank liquidity and liquidity risk. Some of them characterize the essence of liquidity and various aspects of liquidity risk (such as Adrian and Shin, 2009; Allen and Gale, 1994; or Tirole, 2011), some other studies investigate determinants of liquidity risk (focusing on the group of CEE countries, we should mention e.g. Dinger, 2009; Munteanu, 2012; Roman and Sargu, 2014; or Vodová, 2013a). However, in spite of an increasing number of financial conglomerates and of the higher attention of regulators and supervision bodies to financial conglomerates, an important gap still exists in the empirical literature. To the knowledge of authors, there is only one study which examined the performance of banks that are part of a financial holding company with that of banks that are not (Shen and Chang, 2012) based on ratios of the concept of CAMEL model. If we look only on liquidity, they have found that banks that are members of a financial holding company had higher level of liquidity than independent banks. Other empirical analyses are still missing so this article therefore addresses and fills this gap in current empirical research.

\section{Methodology}

As it was mentioned above, the chosen liquidity risk management strategy is reflected in values of some liquidity ratios. Liquidity ratios can help to identify main liquidity trends (Vodová, 2013b). We will use following three liquidity ratios: share of liquid assets in total assets, share of loans in deposits and share of net interbank position in total assets. The share of liquid assets in total assets (LIA) shows which part of the total assets can be readily converted to cash. This liquid asset ratio should give us information about the general liquidity shock absorption capacity of a bank. The higher the share of liquid assets in total assets, the higher the capacity to absorb liquidity shock, given that market liquidity is the same for all banks in the sample. Since we use the BankScope measure of liquid assets, the term "liquid assets" includes cash, government bonds, short-term claims on other banks (including certificates of deposit), and where appropriate the trading portfolio. BankScope harmonizes data from different jurisdictions to arrive at a globally comparable indicator. This is particularly advantageous in this case when comparing banks from different countries.

The second ratio relates illiquid assets to liquid liabilities. The share of loans in deposits (LOD) may be interpreted as following: the higher this ratio the less liquid the bank is. This loan to the deposit ratio also provides information which part of loans provided to non-bank clients is financed from deposits of non-bank customers. Values lower than $100 \%$ mean that loans are fully financed from clients' deposits. Values higher than $100 \%$ signal that the bank needs also other source of funding such as interbank loans or funds from debt securities issuance. Although large proportions of clients' deposits are in the form of demand deposits, they are generally a stable source of funding. In terms of liquidity risk, banks should prefer a lower value of this ratio. A high value of the LOD ratio indicates that the bank is more vulnerable, especially in case of market turbulence.

The last ratio captures the activity of banks on the interbank market. To be able to compare different-sized banks, this ratio measures the share of a net interbank position (i.e. the 
difference between dues from banks and dues to banks) in the total assets of the bank. The value of this ratio is positive for net lenders and negative for net borrowers. Comparing with clients' deposits, raising funds in the interbank market is significantly more flexible. However due to the low stability of this source of funding (a bank is constantly under the control of its counterparties which in case of doubts about the financial situation of the bank may not roll over loans), it is more risky. Banks who are net borrowers are thus much more vulnerable.

Banks who prefer the defensive strategy of liquidity risk management would probably have a higher value of the liquid asset ratio, a lower value of the loan to the deposit ratio and a positive value of the net interbank position. On the other hand, banks focusing on the offensive strategy of liquidity risk management would prefer a lower value of the LIA, a higher value of the LOD and a negative value of the NIP. Moreover, the comparison of values of liquidity ratios of parent bank and its subsidiaries may sometimes indicate that some forms of intra-group support could be used. These are the reasons why we will compare values of ratios of subsidiary banks with the parent bank, values of ratios of subsidiary banks with values for corresponding banking sectors and values of ratios of two financial groups (Societe Generale and Erste Group).

\section{Data used}

Erste Group and Societe Generale Group belong to the largest financial conglomerates in CEE countries. Focusing on Erste Group, about 46,000 employees serve clients in 2,800 branches. Measured by the sum of total assets, the parent company is the biggest bank in Austria and the $81^{\text {st }}$ biggest bank in the Word. Erste Group Bank is a universal bank. With a presence in 76 countries, more than 148,000 employees and 32 million individual customers, Societe Generale is one of the leading financial services groups. Measured by the sum of total assets, the parent company Societe Generale is the third biggest bank in France and the eighteens biggest bank in the world. Societe Generale (hereinafter also SG) is a universal bank, too.

Table 2: Information about banks in the sample

\begin{tabular}{|l|l|l|l|}
\hline Bank & Country & $\begin{array}{l}\text { Bank size } \\
\text { (country/world) }\end{array}$ & Period \\
\hline \multicolumn{3}{|c|}{ Erste Group } \\
\hline Erste Group Bank (parent company) & Austria & $1 . / 81$. & $2004-2013$ \\
\hline Erste\&Steiermärkische Bank & Croatia & $2 . / 1260$. & $2004-2013$ \\
\hline Česká spořitelna & Czech Republic & $2 . / 453$. & $2004-2013$ \\
\hline Erste Bank Hungary & Hungary & $2 . / 1170$. & $2004-2013$ \\
\hline Banca Comerciale Rom. Chisinau & Moldova & $12 . / 12504$. & $2006-2013$ \\
\hline Erste Bank Podgorica & Montenegro & $2 . /$ - & $2004-2013$ \\
\hline Banca Comerciala Romana & Romania & $1 . / 808$. & $2004-2013$ \\
\hline Erste Bank Novi Sad & Serbia & $12 . / 4879$. & $2004-2013$ \\
\hline Slovenská sporitelňa & Slovakia & $1 . / 1026$. & $2004-2013$ \\
\hline \multicolumn{2}{|l|}{ Societe Generale Group } \\
\hline Societe Generale (parent company) & France & $3 . / 18$. & $2004-2013$ \\
\hline Banka Societe Generale Albania & Albania & $7 . / 6152$. & $2004-2013$ \\
\hline Societe Generale Expressbank & Bulgaria & $8 . / 2871$. & $2004-2013$ \\
\hline Societe Generale - Splitska banka & Croatia & $6 . / 2121$. & $2004-2013$ \\
\hline Komerční banka & Czech Republic & $3 . / 514$. & $2004-2013$ \\
\hline Ohridska Banka & Macedonia & $3 . / 6181$. & $2004-2013$ \\
\hline CB Mobiasbanca & Moldova & $6 . / 8385$. & $2004-2013$ \\
\hline Societe Generale Banka Montenegro & Montenegro & $3 . / 7274$. & $2004-2013$ \\
\hline Euro Bank & Poland & $20 . / 2438$. & $2005-2013$ \\
\hline BRD - Group Societe Generale & Romania & $2 . / 1068$. & $2004-2013$ \\
\hline Societe Generale Banka Srbija & Serbia & $4 . / 2986$. & $2004-2013$ \\
\hline SKB Banka & Slovenia & $5 . / 2395$. & $2004-2013$ \\
\hline Source: authors processing. &
\end{tabular}

Source: authors' processing. 
Table 2 provides more details about banks which are included in our sample (name of the bank, country, position of the bank in the country and in the world). Although globally banks from both financial groups cannot be seen as very large banks (as we can see from its worldwide rank), these banks belong mostly to leading banking institutions in the region of CEE countries. We used unconsolidated balance sheet data, mostly over the period from 2004 to 2013, which were obtained from the BankScope database.

\section{Results and discussion}

The values of the share of liquid assets in total assets for all banks, all countries (average values for individual banking sectors) and both parent banks are presented in Appendix 1 . Figure 2 shows the values of this ratio for both parent banks. Median values of individual banks from both financial groups and median values for corresponding countries (banking sectors) are included for comparison. We can see quite a interesting situation: the median values of the LIA ratio for subsidiary banks from both financial groups (Erste and Societe Generale) are very similar. In some years, liquidity of subsidiaries from Erste Group are slightly higher, such as in 2006, 2009-2013, in other years, banks belonging to the Societe Generale Group are more liquid.

Figure 2: Median values of the LIA ratio

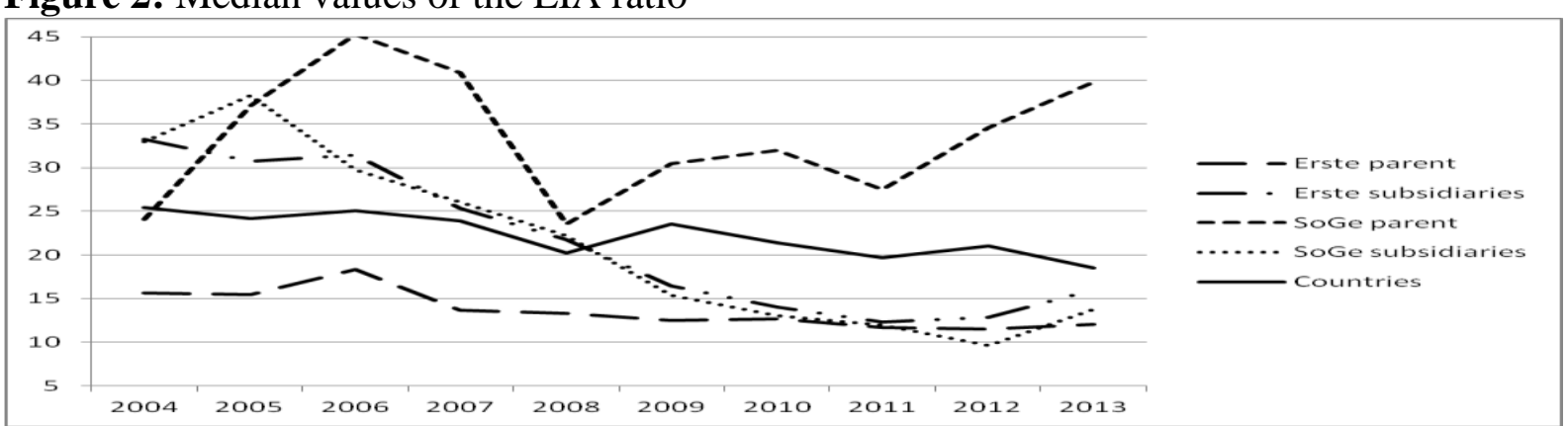

Source: authors' calculations.

Looking at individual banking groups, we can see significant differences in the strategy of liquidity risk management. In case of Erste Group, the liquidity of a parent bank is lower than the liquidity of its subsidiary banks. Of course, there are some exceptions in some years, such as Erste\&Steiermärkische Bank (in 2010-2013), Erste Bank Hungary (in 2004, 2006-2008), Erste Bank Podgorica (in 2004, 2009-2011), Banca Comerciala Romana (in 2011-2013), Erste Bank Novi Sad (in 2010 and 2012) and Slovenská sporitel'ňa (in 2011-2013). On the contrary, the situation in Societe Generale Group is completely different: with the only exception of the year 2004, the liquidity of a parent bank is higher than the liquidity of its subsidiary banks. Moreover, the gap between these two values has been increasing in recent years. Euro Bank, CB Mobiasbanca and SKB Banka are less liquid for the whole analyzed period; SG Expressbank and SG - Splitska banka for the period 2005-2013; and SG Banka Montenegro for the period 2006-2013. It is evident, that at the beginning of 2007, the majority of banks belonging to the Societe Generale Group became less liquid than the parent bank.

If we compare the values of the liquid asset ratio of subsidiary banks with average values in the corresponding banking sector, the situation for Erste Group and Societe Generale Group also differs. In the first part of the analyzed period, liquidity of banks belonging to Erste Group was mostly above the average of the banking sector. However, in the second part of the analyzed period, the liquidity of banks from Erste Group is below the average of the corresponding countries, with the exception of banks from Hungary and Montenegro. On the contrary, in most cases, the liquidity of banks belonging to Societe Generale Group is below 
the average of the banking sector for the whole analyzed period, some exceptions are only banks from Albany, the Czech Republic, Macedonia and Serbia, but only during the first years. The decreasing liquidity of most banks in the sample, together with the fact that their liquidity has been mostly lower than in corresponding banking sectors ever since 2008, may suggest that maybe we should take into account also the possibility of intra-group support in both financial groups. Values of the liquid asset ratio of parent banks and their subsidiaries indicate the higher probability of upstream support within these two financial groups.

Figure 3: Median values of the LOD ratio

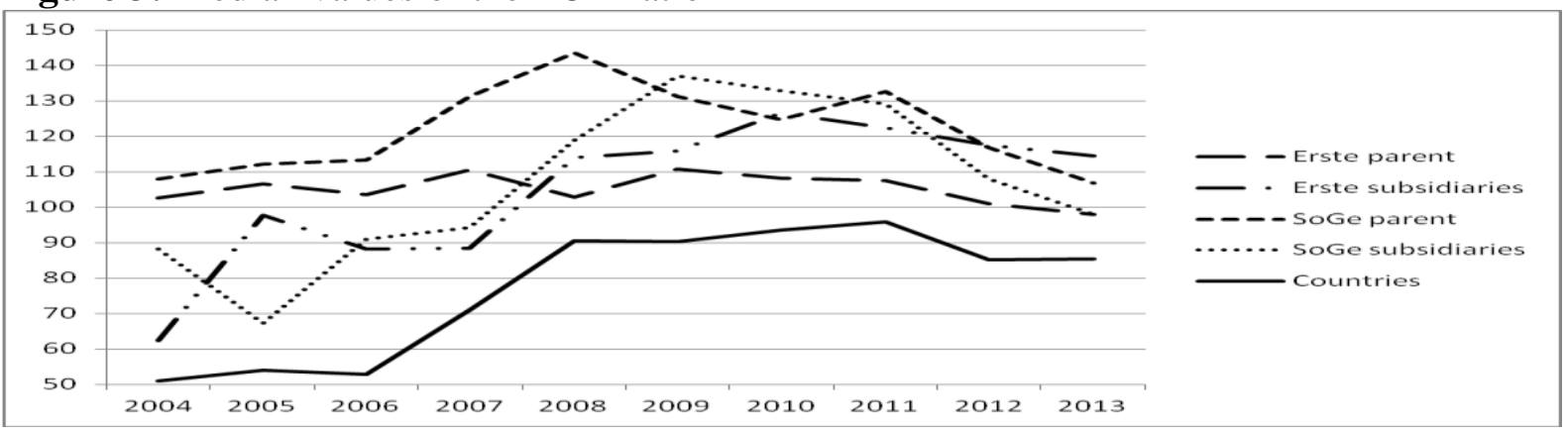

Source: authors' calculations.

Median values of the loan to the deposit ratio can be found in Figure 3, more detailed results in Appendix 2. Again, the result for subsidiaries in both groups are quite similar, the difference between them is greater only in 2009. In case of this ratio, we can see also other similarities. The liquidity of subsidiaries and parent banks from both financial groups is lower than the liquidity in corresponding banking sectors (which is proved by higher values of the LOD ratio).

The strategy of liquidity risk management in the area of the way how to finance a lending activity is also very similar to financial groups. Until 2008, both parent banks had higher values of the loan to the deposit ratio than their subsidiaries. Even if clients' deposits were sufficient for financing of lending activities of subsidiaries, parent banks needed also other sources of finance (their LOD ratio was higher than 100\%). Since 2009, subsidiaries have become more dependent also on other sources of funding, even more dependent than the parent banks. In the second half of the analyzed period, only Česká spořitelna and Slovenská sporitel'ňa from Erste Group and Banka Societe Generale Albania, Komerční banka and Ohridska Banka from Societe Generale Group have values of the LOD ratio lower than 100\% which means these banks are less vulnerable than their parent banks and the majority of banks from corresponding financial groups.

The last ratio assesses the activity of banks on the interbank market. Median values of the NIP ratio are presented in Figure 4, more detailed results in Appendix 3. In both financial groups, the strategies for interbank market transactions are again very similar. Subsidiaries banks have substantially a better (i.e. safer) net interbank position than parent banks. Even if they are net borrowers in some years, their position is better. Especially in the period of 2008-2010, the development trend of the median value of the NIP ratio for subsidiaries from both group is totally the same - after the worsening of the position, the improvement came. The safest position on the interbank market following banks hold: Česká spořitelna and Erste Bank Podgorica from Erste Group and Komerční banka and CB Mobiasbanca from Societe Generale Group. The net interbank position of parent banks is worse; they are net borrowers for the whole analyzed period. 
Figure 4: Median values of the NIP ratio

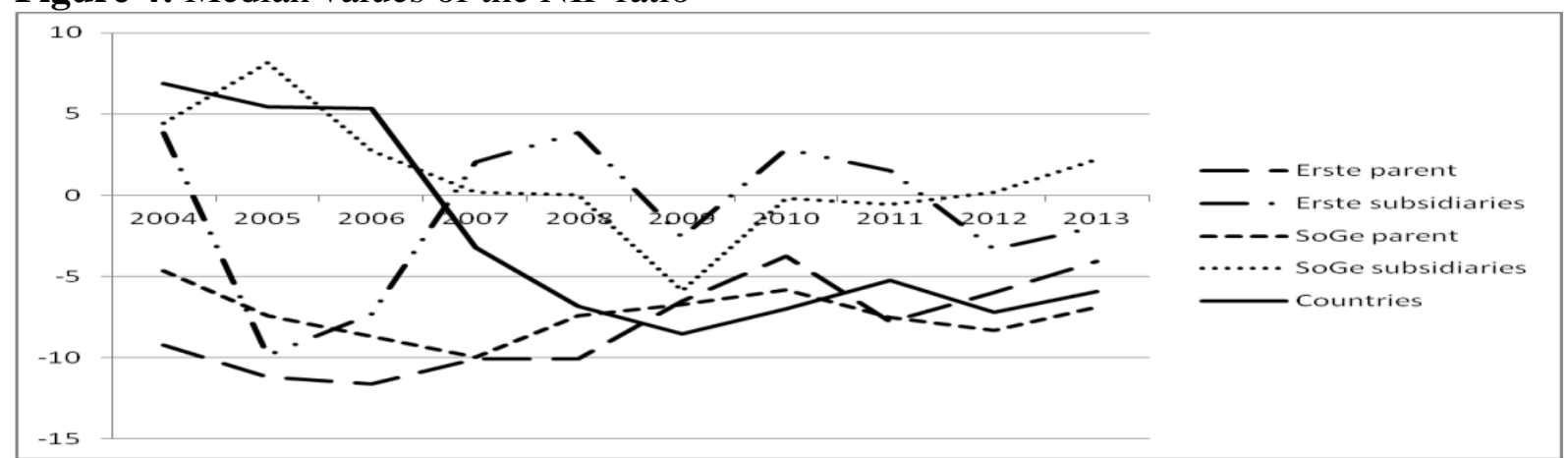

Source: authors' calculations.

In all cases, the difference between values of all three liquidity ratios for parent banks, subsidiaries banks and corresponding banking sectors is statistically significant, which we confirmed by the results of an analysis of variance for a single factor (ANOVA).

\section{Conclusion}

The aim of this paper was to compare the strategy of liquidity risk management of banks belonging to Erste Group and Societe Generale Group in the region of Central and Eastern Europe. We have calculated three liquidity ratios (the share of liquid assets in total assets, the share of loans in deposits and the share of the net interbank position in total assets) for all banks in the sample (which means two parent banks and nineteen subsidiary banks) and for thirteen corresponding banking sectors for last ten years. Then we have compared values of ratios of subsidiary banks with the parent bank, values of ratios of subsidiary banks with values for corresponding banking sectors and values of ratios of two financial groups.

The results have showed us that in terms of the level of liquid assets, the strategy of both financial groups differ. The liquidity of Erste Group Bank as a parent bank is lower than the liquidity of its subsidiaries which is opposite than in case of Societe Generale Group, where the parent bank holds a higher amount of liquid assets. However, the liquidity position of subsidiary banks from both financial groups is very similar. The decreasing liquidity of most banks in the sample suggests that maybe some forms of intra-group support in both financial groups could take place; it is more probable that it was in the form of upstream support. The strategy of financing of lending activities is almost the same for both financial groups, as both parent banks had a higher loan to the deposit ratio than their subsidiaries until 2008. Since 2009, subsidiary banks have become more dependent also on other sources of funding, even more dependent than the parent banks. When it comes to the activity on the interbank market, the strategies are again very similar: subsidiaries have substantially a safer position than both parent banks which are net borrowers for the whole analyzed period.

The results of all three ratios have confirmed that each bank has its own strategy which combines defensive and offensive approaches. In terms of sources of funding, subsidiaries are much safer than both parents bank. Concerning the buffer of liquid assets, Societe Generale as a parent bank is much more liquid than its subsidiaries and also than Erste Group Bank and its subsidiaries. Differences between values of all ratios for parents, subsidiaries and banking sectors are statistically significant which is proved by the analysis of variance.

\section{References}

[1] ADRIAN, T. and H. S. SHIN, 2009. Money, Liquidity and Monetary Policy. American Economic Review, 99(2), 600-605. ISSN 0002-8282. 
[2] ALLEN, F. and D. GALE, 1994. Limited Market Participation and Volatility of Asset Prices. American Economic Review, 84(4), 933-955. ISSN 0002-8282.

[3] ANGERMÜLLER, N. O. and S. ZERANSKI, 2008. New approaches for efficient liquidity management in the light of recent regulation and developments. Journal of International Banking Law \& Regulation, 23(10), 506-513. ISSN 1742-6812.

[4] BIS, 2006. The Management of Liquidity Risk in Financial Groups. Basel: Bank for International Settlements. ISBN 92-9197-712-8.

[5] BIS, 2012. Report on intra-group support measures. Basel: Bank for International Settlements. ISBN 92-9197-105-7.

[6] DINGER, V., 2009. Do foreign-owned banks affect banking systém liquidity risk? Journal of Comparative Economics, 37(4), 647-657. ISSN 0147-5967.

[7] GONGOL, T. a P. VODOVÁ, 2014. Liquidity Risk Regulation. Financial Assets and Investing, 5(1), 7-21. ISSN 1804-5081.

[8] CHOUDHRY, M., 2012. The Principles of Banking. Singapore: Wiley. ISBN 978-0-47082521-1.

[9] JOINT FORUM, 1999. Capital Adequacy Principles paper. Bank for International Settlement [online]. [vid. 5. ledna 2015]. Dostupné z: http://www.bis.org/publ/bcbs47ch2.pdf

[10] MUNTEANU, I., 2012. Bank liquidity and its determinants in Romania. Proceedia Economics and Finance, 2012(3), 993-998. ISSN 2212-5671.

[11] NIKOLAU, K., 2009. Liquidity (Risk) Concepts. Definitions and Interactions. ECB Working Paper Series, 1008.

[12] ROMAN, A. and A. C. SARGU, 2014. Banks liquidity risk analysis in the new European Union member countries: evidence from Bulgaria and Romania. Proceedia Economics and Finance, 2014(15), 569-576. ISSN 2212-5671.

[13] RUOZI, R. a P. FERRARI, 2013. Liquidity Risk Management in Banks. Economic and Regulatory Issues. Heidelberg: Springer. ISBN 978-3-642-29580-5.

[14] SHEN, C. H. and Y. CHANG, 2012. To Join or Not to Join? Do Banks that are Part of a Financial Holding Company Perform Better than Banks that are Not? Contemporary Economic Policy, 30(1), 113-128. ISSN 1465-7287.

[15] TIROLE, J., 2011. Illiquidity and all its friends. Journal of Economic Literature, 49(2), 287-325. ISSN 0022-0515.

[16] VENTO, G. A. and P. LA GANGA, 2009. Bank Liquidity Risk Management and Supervision: Which Lessons from Recent Market Turmoil? Journal of Money, Investment and Banking, 2009(10), 79-126. ISSN 1450-288X.

[17] VODOVÁ, P., 2013a. Liquid assets in banking: What matters in the Visegrad Countries? E+M Ekonomie + Management, 16(3), 113-129. ISSN 1212-3609.

[18] VODOVÁ, P., 2013b. Liquidity risk of banks in the Visegrad Countries. An empirical analysis of bank liquidity, its determinants and liquidity risk sensitivity. Saarbrücken: Lambert Academic Publishing. 214 s. ISBN 978-3-659-49360-7. 
Appendix 1: Values of the LIA ratio

\begin{tabular}{|c|c|c|c|c|c|c|c|c|c|c|}
\hline Bank & 2004 & 2005 & 2006 & 2007 & 2008 & 2009 & 2010 & 2011 & 2012 & 2013 \\
\hline \multicolumn{11}{|c|}{ Erste Group } \\
\hline Erste Group Bank (parent comp.) & 47.1 & 35.2 & 30.5 & 30.1 & 32.2 & 15.3 & 12.5 & 7.4 & 11.1 & 12.1 \\
\hline Erste\&Steiermärkische Bank & 21.6 & 26.0 & 22.6 & 14.1 & 20.1 & 21.7 & 25.4 & 15.8 & 14.6 & 18.0 \\
\hline Česká spořitelna & 15.0 & 18.2 & 11.9 & 11.8 & 11.7 & 17.5 & 14.2 & 21.4 & 19.7 & 20.4 \\
\hline Erste Bank Hungary & & & 32.4 & 17.6 & 14.9 & 39.5 & 26.4 & 16.5 & 15.9 & 14.6 \\
\hline Banca Comerciale Rom. Chisinau & 15.4 & 34.6 & 50.4 & 37.7 & 17.0 & 11.0 & 10.5 & 5.4 & 16.0 & 20.8 \\
\hline Erste Bank Podgorica & 48.9 & 34.4 & 39.1 & 33.2 & 23.4 & 17.8 & 16.7 & 9.3 & 7.9 & 9.5 \\
\hline Banca Comerciala Romana & 33.9 & 30.7 & 51.8 & 43.9 & 24.3 & 15.1 & 7.0 & 15.3 & 10.2 & 17.4 \\
\hline Erste Bank Novi Sad & 33.3 & 30.7 & 27.7 & 20.6 & 26.2 & 13.3 & 13.8 & 8.2 & 5.8 & 3.4 \\
\hline Slovenská sporitel'ňa & 47.1 & 35.2 & 30.5 & 30.1 & 32.2 & 15.3 & 12.5 & 7.4 & 11.1 & 12.1 \\
\hline \multicolumn{11}{|c|}{ Societe Generale } \\
\hline Societe Generale (parent comp.) & 33.5 & 45.9 & 65.8 & 69.7 & 8.4 & 5.2 & 9.8 & 9.5 & 9.6 & 11.4 \\
\hline Banka Societe Generale Albania & 25.3 & 31.5 & 22.4 & 15.6 & 13.9 & 12.4 & 7.1 & 10.8 & 9.6 & 9.1 \\
\hline Societe Generale Expressbank & 32.6 & 31.3 & 24.5 & 26.0 & 22.6 & 15.4 & 19.6 & 19.6 & 19.6 & 16.3 \\
\hline Societe Generale - Splitska banka & 53.6 & 51.2 & 39.9 & 33.1 & 26.6 & 23.2 & 20.8 & 16.6 & 15.9 & 21.4 \\
\hline Komerční banka & 43.6 & 59.5 & 38.1 & 62.5 & 31.9 & 13.1 & 13.1 & 31.6 & 31.3 & 32.8 \\
\hline Ohridska Banka & 21.0 & 32.7 & 25.1 & 20.9 & 33.8 & 21.9 & 28.3 & 15.1 & 14.0 & 16.8 \\
\hline CB Mobiasbanca & 25.4 & 48.8 & 23.1 & 22.5 & 9.9 & 17.9 & 16.9 & 8.1 & 8.0 & 10.9 \\
\hline Soc. Generale Banka Montenegro & & 8.8 & 29.7 & 19.6 & 13.4 & 6.7 & 4.3 & 4.4 & 3.5 & 8.2 \\
\hline Euro Bank & 33.3 & 42.2 & 31.3 & 30.1 & 29.1 & 21.6 & 21.5 & 20.9 & 20.8 & 23.3 \\
\hline BRD - Group Societe Generale & 34.8 & 38.2 & 45.3 & 36.9 & 22.2 & 17.5 & 5.7 & 12.0 & 9.2 & 13.8 \\
\hline Societe Generale Banka Srbija & 13.5 & 19.0 & 12.3 & 9.3 & 8.1 & 10.4 & 6.8 & 3.5 & 4.5 & 6.3 \\
\hline SKB Banka & 33.5 & 45.9 & 65.8 & 69.7 & 8.4 & 5.2 & 9.8 & 9.5 & 9.6 & 11.4 \\
\hline \multicolumn{11}{|c|}{ Countries - banking sectors } \\
\hline Albania & 23.5 & 20.9 & 31.7 & 28.4 & 22.0 & 23.6 & 21.4 & 19.7 & 21.0 & 21.1 \\
\hline Bulgaria & 26.1 & 27.3 & 29.7 & 23.9 & 40.1 & 38.9 & 35.4 & 36.1 & 39.3 & 40.6 \\
\hline Croatia & 37.5 & 33.4 & 32.0 & 32.8 & 31.6 & 30.3 & 30.6 & 23.5 & 24.8 & 17.5 \\
\hline Czech Republic & 25.4 & 30.4 & 25.1 & 20.5 & 17.9 & 17.4 & 17.2 & 16.7 & 17.8 & 24.4 \\
\hline Hungary & 15.4 & 14.5 & 14.3 & 13.2 & 9.9 & 10.0 & 9.3 & 10.6 & 11.1 & 12.0 \\
\hline Macedonia & 50.3 & 52.4 & 49.9 & 49.7 & 43.6 & 42.2 & 40.5 & 35.3 & 37.5 & 31.7 \\
\hline Moldova & 40.1 & 38.1 & 32.8 & 38.4 & 41.5 & 44.8 & 33.0 & 39.2 & 41.7 & 46.9 \\
\hline Montenegro & 39.5 & 53.5 & 48.8 & 31.6 & 18.3 & 23.8 & 29.4 & 23.3 & 22.3 & 20.4 \\
\hline Poland & 21.1 & 24.2 & 21.6 & 17.4 & 14.2 & 12.3 & 9.0 & 8.9 & 9.8 & 11.0 \\
\hline Romania & 27.2 & 23.1 & 23.8 & 23.1 & 17.4 & 16.0 & 12.3 & 10.6 & 10.2 & 14.4 \\
\hline Serbia & 17.8 & 18.7 & 24.1 & 61.5 & 49.4 & 49.6 & 38.6 & 41.6 & 38.8 & 18.5 \\
\hline Slovenia & 16.1 & 14.9 & 18.7 & 15.9 & 20.2 & 13.4 & 10.6 & 8.8 & 9.7 & 6.4 \\
\hline Slovakia & 14.3 & 16.5 & 16.0 & 13.8 & 12.5 & 13.4 & 11.7 & 10.7 & 9.2 & 11.8 \\
\hline
\end{tabular}

Source: authors' calculations. 
Appendix 2: Values of the LOD ratio

\begin{tabular}{|c|c|c|c|c|c|c|c|c|c|c|}
\hline Bank & 2004 & 2005 & 2006 & 2007 & 2008 & 2009 & 2010 & 2011 & 2012 & 2013 \\
\hline \multicolumn{11}{|c|}{ Erste Group } \\
\hline Erste Group Bank (parent comp.) & 62 & 98 & 108 & 98 & 99 & 106 & 115 & 124 & 123 & 117 \\
\hline Erste\&Steiermärkische Bank & 52 & 57 & 60 & 70 & 66 & 70 & 66 & 69 & 69 & 70 \\
\hline Česká spořitelna & 115 & 137 & 160 & 159 & 177 & 176 & 185 & 157 & 116 & 112 \\
\hline Erste Bank Hungary & & & 257 & 675 & 1092 & 373 & 128 & 153 & 163 & 131 \\
\hline Banca Comerciale Rom. Chisinau & 400 & 128 & 60 & 74 & 129 & 125 & 142 & 147 & 116 & 118 \\
\hline Erste Bank Podgorica & 61 & 74 & 103 & 125 & 138 & 133 & 125 & 121 & 118 & 101 \\
\hline Banca Comerciala Romana & 93 & 105 & 73 & 78 & 96 & 99 & 132 & 119 & 177 & 157 \\
\hline Erste Bank Novi Sad & 33 & 53 & 60 & 66 & 64 & 74 & 70 & 78 & 80 & 79 \\
\hline Slovenská sporitel’ňa & 62 & 98 & 108 & 98 & 99 & 106 & 115 & 124 & 123 & 117 \\
\hline \multicolumn{11}{|c|}{ Societe Generale } \\
\hline Societe Generale (parent comp.) & 87 & 56 & 35 & 31 & 44 & 55 & 51 & 64 & 66 & 66 \\
\hline Banka Societe Generale Albania & 89 & 85 & 93 & 127 & 171 & 167 & 145 & 130 & 128 & 117 \\
\hline Societe Generale Expressbank & 134 & 139 & 143 & 125 & 135 & 137 & 133 & 129 & 108 & 98 \\
\hline Societe Generale - Splitska banka & 42 & 49 & 52 & 56 & 66 & 67 & 71 & 77 & 79 & 76 \\
\hline Komerční banka & 52 & 36 & 40 & 38 & 62 & 85 & 82 & 79 & 75 & 85 \\
\hline Ohridska Banka & 97 & 73 & 87 & 84 & 109 & 91 & 70 & 90 & 101 & 90 \\
\hline CB Mobiasbanca & 103 & 58 & 108 & 104 & 199 & 147 & 171 & 183 & 116 & 104 \\
\hline Soc. Generale Banka Montenegro & & 81 & 117 & 216 & 396 & 210 & 202 & 207 & 177 & 154 \\
\hline Euro Bank & 77 & 67 & 91 & 94 & 115 & 114 & 110 & 107 & 102 & 74 \\
\hline BRD - Group Societe Generale & 87 & 64 & 64 & 90 & 119 & 148 & 206 & 133 & 139 & 128 \\
\hline Societe Generale Banka Srbija & 94 & 115 & 147 & 181 & 191 & 181 & 166 & 156 & 148 & 120 \\
\hline SKB Banka & 87 & 56 & 35 & 31 & 44 & 55 & 51 & 64 & 66 & 66 \\
\hline \multicolumn{11}{|c|}{ Countries - banking sectors } \\
\hline Albania & 19 & 24 & 33 & 42 & 54 & 60 & 58 & 58 & 54 & 51 \\
\hline Bulgaria & 47 & 54 & 53 & 71 & 97 & 94 & 95 & 89 & 83 & 79 \\
\hline Croatia & 63 & 73 & 80 & 82 & 110 & 113 & 115 & 120 & 111 & 108 \\
\hline Czech Republic & 44 & 45 & 52 & 61 & 77 & 79 & 79 & 84 & 83 & 84 \\
\hline Hungary & 110 & 110 & 116 & 121 & 124 & 117 & 117 & 103 & 91 & 83 \\
\hline Macedonia & 51 & 48 & 47 & 68 & 78 & 74 & 74 & 71 & 68 & 68 \\
\hline Moldova & 51 & 56 & 63 & 66 & 87 & 79 & 80 & 96 & 85 & 96 \\
\hline Montenegro & 102 & 74 & 83 & 135 & 130 & 112 & 104 & 101 & 89 & 86 \\
\hline Poland & 59 & 54 & 63 & 72 & 90 & 84 & 83 & 85 & 81 & 99 \\
\hline Romania & 34 & 38 & 49 & 69 & 80 & 90 & 82 & 80 & 75 & 85 \\
\hline Serbia & 53 & 50 & 35 & 74 & 104 & 95 & 119 & 115 & 123 & 122 \\
\hline Slovenia & 45 & 47 & 47 & 55 & 82 & 90 & 93 & 96 & 87 & 85 \\
\hline Slovakia & 68 & 77 & 96 & 132 & 151 & 140 & 136 & 126 & 126 & 97 \\
\hline
\end{tabular}

Source: authors' calculations. 
Appendix 3: Values of the NIP ratio

\begin{tabular}{|c|c|c|c|c|c|c|c|c|c|c|}
\hline Bank & 2004 & 2005 & 2006 & 2007 & 2008 & 2009 & 2010 & 2011 & 2012 & 2013 \\
\hline \multicolumn{11}{|c|}{ Erste Group } \\
\hline Erste Group Bank (parent comp.) & 28.0 & -14.9 & -27.6 & -14.4 & 6.3 & 8.1 & 4.8 & 1.7 & -25.3 & -22.9 \\
\hline Erste\&Steiermärkische Bank & 7.6 & 9.6 & 3.7 & 0.9 & 4.1 & 9.2 & 13.9 & 2.8 & 1.7 & -1.8 \\
\hline Česká spořitelna & -24.9 & -28.4 & -36.4 & -35.6 & -50.2 & -47.2 & -47.4 & -44.9 & -34.7 & -27.4 \\
\hline Erste Bank Hungary & & & -25.9 & 9.7 & 2.3 & -42.7 & 18.7 & 4.3 & 4.8 & 3.0 \\
\hline Banca Comerciale Rom. Chisinau & 3.8 & 16.3 & 23.0 & 15.3 & 10.4 & 5.1 & 5.4 & 1.3 & 8.6 & 7.1 \\
\hline Erste Bank Podgorica & -9.6 & -9.9 & -18.3 & -30.4 & -31.2 & -27.7 & -27.2 & -28.4 & -29.3 & -22.9 \\
\hline Banca Comerciala Romana & -10.4 & -15.3 & 15.8 & 20.8 & 12.4 & 2.5 & 0.7 & 7.8 & 0.6 & 7.7 \\
\hline Erste Bank Novi Sad & 13.3 & 8.6 & 8.3 & 3.1 & 3.5 & -7.7 & 0.8 & -7.4 & -7.3 & -2.1 \\
\hline Slovenská sporitel’ňa & 28.0 & -14.9 & -27.6 & -14.4 & 6.3 & 8.1 & 4.8 & 1.7 & -25.3 & -22.9 \\
\hline \multicolumn{11}{|c|}{ Societe Generale } \\
\hline Societe Generale (parent comp.) & 11.3 & 8.2 & -2.0 & 1.5 & -7.4 & -5.9 & -2.1 & -2.8 & -1.7 & -4.8 \\
\hline Banka Societe Generale Albania & 15.9 & 9.3 & 4.8 & -20.9 & -37.4 & -29.1 & -15.9 & -6.8 & -12.6 & 2.9 \\
\hline Societe Generale Expressbank & -30.4 & -1.7 & 6.9 & 17.5 & 1.6 & 3.2 & 9.8 & 13.4 & 12.1 & 4.5 \\
\hline Societe Generale - Splitska banka & 45.0 & 41.6 & 32.5 & 28.3 & 19.3 & 16.2 & 11.9 & 8.5 & 2.4 & 6.0 \\
\hline Komerční banka & 38.2 & 25.1 & 21.5 & -0.1 & 0.1 & 0.5 & -0.2 & -0.6 & 0.7 & 0.8 \\
\hline Ohridska Banka & -13.3 & 18.8 & 2.7 & 2.3 & 24.3 & 15.2 & 21.0 & 1.8 & 0.2 & 3.7 \\
\hline CB Mobiasbanca & 1.0 & 18.5 & 0.0 & 0.0 & 0.0 & 0.0 & 0.0 & 0.0 & 3.2 & 2.6 \\
\hline Soc. Generale Banka Montenegro & & -11.4 & -8.9 & -31.8 & -44.7 & -31.4 & -41.2 & -44.7 & -46.7 & -35.2 \\
\hline Euro Bank & 0.9 & 1.6 & -1.8 & 0.2 & -14.5 & -11.5 & -2.4 & -6.2 & -7.8 & -1.3 \\
\hline BRD - Group Societe Generale & -13.0 & 4.4 & 15.1 & 12.3 & 4.2 & -8.7 & 3.6 & 7.3 & 1.5 & 2.2 \\
\hline Societe Generale Banka Srbija & 7.8 & -17.6 & -27.9 & -34.3 & -38.5 & -37.1 & -33.9 & -31.1 & -29.5 & -17.6 \\
\hline SKB Banka & 11.3 & 8.2 & -2.0 & 1.5 & -7.4 & -5.9 & -2.1 & -2.8 & -1.7 & -4.8 \\
\hline \multicolumn{11}{|c|}{ Countries - banking sectors } \\
\hline Albania & 7.5 & 5.4 & 12.8 & 3.7 & 0.4 & 0.5 & -0.9 & 0.1 & 1.4 & -0.3 \\
\hline Bulgaria & 3.6 & 1.4 & 5.3 & -6.5 & -9.1 & -8.3 & -8.7 & -4.8 & -6.0 & -4.5 \\
\hline Croatia & 19.9 & 14.7 & 9.0 & 10.8 & -6.4 & -9.6 & -4.6 & -7.0 & -9.8 & -3.3 \\
\hline Czech Republic & 14.2 & 15.9 & 10.8 & 9.4 & -1.1 & -2.1 & -2.1 & -2.4 & -2.8 & -9.4 \\
\hline Hungary & -7.3 & -7.4 & -7.8 & -12.4 & -18.9 & -16.3 & -14.9 & -13.7 & -11.1 & -7.5 \\
\hline Macedonia & 43.5 & 46.9 & 45.1 & -4.2 & -6.8 & -8.8 & -7.8 & -5.3 & -6.5 & -6.5 \\
\hline Moldova & 32.0 & 26.9 & 22.6 & 26.1 & -4.5 & 4.5 & 3.8 & -3.1 & -3.1 & -5.9 \\
\hline Montenegro & 8.1 & 20.6 & 10.7 & -3.2 & -5.1 & -2.6 & -1.8 & 3.3 & 11.1 & 12.3 \\
\hline Poland & 6.9 & 6.3 & 5.1 & 1.0 & -6.7 & -9.3 & -9.6 & -8.6 & -7.7 & -8.8 \\
\hline Romania & -0.2 & -1.9 & -3.0 & -9.4 & -15.8 & -25.1 & -23.8 & -23.5 & -19.9 & -9.3 \\
\hline Serbia & -1.3 & -8.5 & -1.5 & -13.9 & -17.3 & -9.2 & -13.7 & -13.0 & -13.6 & -4.2 \\
\hline Slovenia & 4.8 & 2.4 & 5.3 & 1.8 & -17.5 & -0.4 & -2.2 & -2.1 & -7.2 & -5.9 \\
\hline Slovakia & 0.3 & -2.6 & -8.3 & -6.6 & -8.6 & -8.5 & -7.0 & -7.8 & -16.5 & -14.5 \\
\hline
\end{tabular}

Source: authors' calculations. 